\title{
Alpha Synuclein Protein Measurement
}

National Cancer Institute

\section{Source}

National Cancer Institute. Alpha Synuclein Protein Measurement. NCI Thesaurus. Code C142272.

The determination of the amount of alpha synuclein protein present in a sample. 